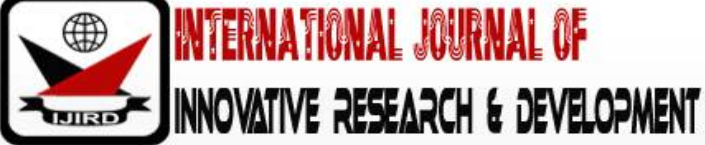

ISSN 2278 - 0211 (Online)

\section{Proximate Composition, Phytochemical and Mineral Analysis of the Fruits of Ficus Capensis}

\begin{tabular}{c}
\hline Dr. P.N. Okoroh \\
Lecturer, Department of Biochemistry, Rhema University, Nigeria \\
Dr. M.C.K. Duru \\
Senior Lecturer, Department of Biochemistry, Rhema University, Nigeria \\
Dr. S.C. Onuoha \\
Senior Lecturer, Department of Biochemistry, University of Port Harcourt, Nigeria \\
Dr. Amadi B.A \\
Senior Lecturer, Department of Biochemistry, University of Port Harcourt, Nigeria \\
\hline
\end{tabular}

\begin{abstract}
:
Proximate, phytochemical and mineral compositions of Ficus capensis fruit were determined using standard methods. Phytochemical screening revealed the presence of tannins, terpenoids, alkaloids, flavonoids, cardiac glycosides, phenol, phytate, oxalate and heamaglutin. The proximate analysis of the fruits of Ficus capensis yielded: moisture (33.17\%), dry matter $(66.29 \%)$, ash $(7.66 \%)$, crude protein $(1.40 \%)$, crude fat $(4.47 \%)$, crude fiber $(3.18 \%)$ and total carbohydrate (49.58\%). Mineral analysis showed that the fruit samples yielded $40.64 \mathrm{mg} / 100 \mathrm{~g}$ calcium, $59.99 \mathrm{mg} / 100 \mathrm{~g}$ magnesium, $45.05 \mathrm{mg} / 100 \mathrm{~g}$ potassium, $6.19 \mathrm{mg} / 100 \mathrm{~g}$ sodium, $7.28: 1$ for potassium to sodium ratio, $25.30 \mathrm{mg} / 100 \mathrm{~g}$ iron, $1.25 \mathrm{mg} / 100 \mathrm{~g}$ copper, and $2.90 \mathrm{mg} / 100 \mathrm{~g}$ manganese. These results showed that the fruit of Ficus capenses was rich in bio active substances, ash, crude fiber, total carbohydrate and mineral nutrients and suggest its use as an alternative source of food and medicinal formulation for human consumption.
\end{abstract}

Keywords: Phytochemical, proximate composition, mineral, ficus capensis

\section{Introduction}

The Food and Agricultural Organization has reported that about one billion people, especially in developing nations depend on wild plants for their diets (Bharucha and Pretty, 2010). They have been reported to be essential constituent of human diet because they supply the body with nutrients such as minerals, vitamins, certain hormone precursors as well as protein and energy (Akubugwo et al., 2007). Khan et al., (2016) highlighted that there has been an increasing interest in wild edible plants in recent years all over the world due to the fact that these plants are good sources of proteins, minerals, vitamins, dietary fiber, carbohydrates, essential fatty acids, antioxidants, phenolic compounds and secondary metabolites. Some wild fruits have been identified to have better nutritional value than cultivated ones. They have been indicated to be rich sources of various vitamins, minerals, fibers and poly phenols, hence, have the capacity to provide several health benefits and consumption of fruits and green leafy vegetables reduces the risk of several diseases like diabetes, cancer, heart disease etc. Ficus capensis thumb belongs to the family Moraceae (Berg, 1991). Its other names include F. guineensis, F. ituriensis, F. riparia and F. thonningiana while its common names are cape fig and broom cluster fig (Berg, 1991). In Nigeria, it has common names such as Ogbaikolo among the Igalas, Opoto in Yoruba, Akoro in Nsukka area of Enugu State, Obada in Edo State, Rimabichehiby by the fulanis and Uwargara in Hausa. The wild plant is distributed from Cape Verde and Senegambia across tropical West Africa to Cameroon and the Central African Republic, eastward to Eritrea, Northern Somalia and Yemen, South wards through all tropical eastern and southern African countries (African plant database, 2013). The plant is a fast-growing, deciduous or evergreen tree and usually grows from 5-12 meters in height, but may attain a height of 35 - 40 meters (Hankey, 2003). The fruits are carried on short or long drooping spurs which may emerge from surface roots, the trunk or especially from lower main branches (Hankey, 2003). The fruits are edible and utilized in fresh or dried form by native people of many regions of the world. They are used to make fig preserve (Hankey, 2003). Mousa et al., (1994) also highlighted that the fruit extracts of some Ficus species exhibit antitumor activity and anti-bacterial activity. The study on the nutritional and therapeutic values of forest foods is very essential because people will be encouraged through the scientific information from the research to consumer greater quantity of food which will eventually provide them with a better balance of nutrients. Recently, researchers all over the world have indicated interest to evaluate wild edible fruits and plants for their nutritional, phytochemical, as well as other features for the well-being of human society. In the present study, the researchers aimed at determining the proximate, phytochemical and mineral compositions of the fruit of Ficus capensis in South-South region of Nigeria. 


\section{Materials and Methods}

\subsection{Collection of Plant Samples}

The fruits of Ficus capensis were harvested from a bush at Ogbogoro in Obio/ Akpor Local Government Area, Rivers State, south-south, Nigeria. The stalks were removed and the fruits rinsed with distilled water, kept in cool condition until all the water droplets have evaporated. They were sun dried and milled. The material sample was kept in a dry container for analysis on dry weight basis. Determination of Proximate Composition:

A part was immediately used for the determination of the proximate composition of the sample. The moisture, crude fat, crude protein ash, fiber and total carbohydrate of the sample was determined in triplicates according to standard methods (AOAC, 2006). The energy value was calculated using the Atwater factors of 4,9, and 4 for protein, fat and carbohydrate respectively (Onyeike and Ehirim, 2001).

\subsection{Preliminary Screening of the Phytochemicals}

Tannins and flavnoids were determined according to the method of AOAC (2006), saponin was determined according to the method of Obadoni and Ochuko, (2001). Alkaloids were determined as reported by Harbone (1973), phytates and cardiac glycosides were determined based on the method of AOAC (2006).

\subsection{Determination of Mineral Elements and Heavy Metals}

The mineral elements and heavy metals (calcium, magnesium, potassium, sodium, and iron, copper and manganese), were analyzed by atomic absorption spectrophotometry using AVANTA GBC spectrophotometer (ver. 2.02) according to the method of AOAC (2006). Statistical Analysis Data presented are the means of the results of three replicates with a standard error of less than $5 \%$.

\section{Results}

\subsection{Proximate Composition and Calorific Value of the fruits of Ficus capensis}

The results of the proximate composition and calorific value of the fruits of Ficus capensis are shown in table 1. Result highlighted the proximate composition of the sample as follows: moisture (33.17 \pm 0.03$)$, dry matter (66.29 \pm 0.02$)$, ash (7.66 \pm 0.02$)$, crude protein ( $1.40 \pm 0.01)$, crude fat (4.47 \pm 0.01$)$, crude fibre (3.18 \pm 0.01$)$, total carbohydrate (49.50 \pm $0.02)$ and calorific value $(244.1 \pm 0.12)$ respectively.

\subsection{Macro-element Composition of the Fruits of Ficus capensis}

The results of the macro-element composition of the fruits of Ficus capensis are shown in table 2. Magnesium was the dominant macro mineral $(59.99 \mathrm{mg} / 100 \mathrm{~g})$. The values for potassium, calcium and sodium were $400.5 \mathrm{gm} / \mathrm{kg}$, $406.4 \mathrm{mg} / \mathrm{kg}$ and $61.9 \mathrm{mg} / \mathrm{kg}$ respectively. The potassium/ sodium ratio was higher in value than the sodium/ potassium ratio. The fruits were found to be rich in the macro-minerals evaluated. The trace element with the highest concentration was iron $(25.30 \mathrm{mg} / 100 \mathrm{~g})$ while copper $(1.25 \mathrm{mg} / 100 \mathrm{~g})$ was the least heavy metal on dry weight basis.

\subsection{Preliminary Qualitative Phytochemical Evaluation of the Fruits of Ficus Capensis}

The qualitative phytochemical evaluation of the fruits of Ficus capensis are shown in table 3. Analysis revealed the presence of alkaloids, saponins, resins, flavonoids, cardiac glycosides, phenol, steroids, terpenoids and tannins respectively,

\subsection{Quantitative Phytochemical Composition of the Fruits of Ficus Capensis}

The results of the quantitative phytochemical composition of the fruits of F. capensis are shown in table 4. Phenol was found to be dominant (64.03\%) and oxalate the least phytochemical $(0.006 \%)$. The fruits were found to contain flavonoids (10.26\%), saponin (10.04\%), tannin (11.50\%) and these values were comparable. Analysis also highlighted heamaglutinin (25.73\%), alkaloid (16.02\%) and cardiac glycoside (6.32\%). 


\begin{tabular}{|lc|}
\hline Paramaters & Amount(\%) \\
\hline Moisture & $33.17 \pm 0.03$ \\
Dry matter & $66.29 \pm 0.02$ \\
Ash & $7.66 \pm 0.02$ \\
Crude protein & $1.40 \pm 0.01$ \\
Crude fat & $4.47 \pm 0.01$ \\
Crude fiber & $3.18 \pm 0.01$ \\
Total carbohydrate & $49.58 \pm 0.02$ \\
Calorific value (Kcal/100g) & $244.1 \pm 0.12$ \\
\hline
\end{tabular}

Table 1: Proximate Composition and Calorific Value of the Fruits of Ficus Capensis

Values Are Means (X) $\pm \mathrm{SD}, \mathrm{N}=3$

\begin{tabular}{|ll|}
\hline \multicolumn{2}{|c|}{ Mineral Composition } \\
\hline Analyte & Concentration(mg/Kg) \\
\hline Calcium & $40.64 \pm 0.00$ \\
Magnesium & $59.99 \pm 0.01$ \\
Potassium & $45.05 \pm 0.00$ \\
Sodium & $6.19 \pm 0.01$ \\
Potassium/sodium ratio & $7.28 \pm 0.00$ \\
Iron & $25.30 \pm 0.02$ \\
Copper & $1.25 \pm 0.00$ \\
Manganese & $2.90 \pm 0.02$ \\
Na/K & 0.14 \\
\hline
\end{tabular}

Table 2: Macro Element/ Trace Mineral Composition of the Fruits of Ficus Capensis Values Are Means $(\mathrm{X}) \pm \mathrm{SD}, \mathrm{N}=3$

\begin{tabular}{|lc|}
\hline Phytochemical & Status \\
\hline Alkaloids & ++ \\
Flavonoids & ++ \\
Saponins & ++ \\
Tannins & ++ \\
Terpenoids/steroids & ++ \\
Phenols & ++ \\
Cardiac glycosides & ++ \\
Resins & +++ \\
\hline
\end{tabular}

Table 3: Preliminary Qualitative Phytochemical Composition of the Fruits of Ficus Capensis +Moderate Concentration +HAppreciable Concentration 


\begin{tabular}{|lc|}
\hline Constituents & amount (\%) \\
\hline Flavonoid & $10.26 \pm 0.02$ \\
Saponin & $10.04 \pm 0.01$ \\
Cardiac glycoside & $6.32 \pm 0.02$ \\
Phenol & $64.3 \pm 0.02$ \\
Haemaglutin & $25.73 \pm 0.00$ \\
Phytate & $0.23 \pm 0.00$ \\
Oxalate & $0.006 \pm 0.00$ \\
Tannin & $11.50 \pm 0.16$ \\
Alkaloid & $16.02 \pm 0.02$ \\
\hline
\end{tabular}

Table 4: Quantitative Phytochemical Composition (\%) of the

Fruits of Ficus Capensis

Constituents Amount (\%)

Values Are Means \pm SD; $\mathrm{N}=3$

\section{Discussions and Conclusion}

\subsection{Discussion}

Proximate analysis (Table 1) revealed that moisture content found in the fruit of F. capensis was higher than the values reported for F. capensis bark, F. capensis leaves by Uzoekwe et al., (2013), G. africanum and T. occidentalis (Dike, 2003) but far lower than the values reported for L.africana, H.crinate, V.anygdalina, T.occidentalis (Okoroh , 2013). The moisture content of any food reflects its water activity (Olutiola et al., 1991) and is utilized in the measurement of food stability against contamination by microorganisms (Uraih and Izuagbe, 1990). Foods with low moisture content can stay longer. The ash content of the fruit of $\mathrm{F}$. capensis was lower compared with the value for $\mathrm{F}$. capensis leaves and $\mathrm{F}$. capensis bark as reported by Uzoekwe et al., (2013) but the values were comparable to that of the leaves of C. cujete (Olaniyi et al., 2018) and higher than the values for U.trinervis and H. myriantha respectively (Andzouana and Mombouli, 2012). Ash content is a reflection of the amount of mineral elements and organic matter present in the fruit. The fruits of F. capensis investigated revealed low amount of crude fiber. The value was lower than the values reported for the bark and leaves of $F$. capensis respectively (Uzoekwe et al., 2013), C. cujete (Olaniyi et al., 2018), A. hybridus (Akubugwo et al., 2007) and V. calvaona (Ayoola and Adeyeye, 2010). Consumption of large amount of the fruits is necessary as fiber aids digestion, softens stool, prevents constipation and enhances bowel movement (Ayoola and Adeyeye, 2010). Dietary fiber is essential to lower serum cholesterol level and reduces the risk of heart diseases, diabetes and breast cancer (Ishida et al., 2000). The study revealed a very low level of crude protein in the fruits compared to the values highlighted by Uzoekwe et al., (2013) but the value was comparable to that reported for S. virosa leaves (Danlami, et al., 2012), but Olaniyi et al., (2018) reported a much higher value. The fruits of F. capensis investigated contained crude fat content higher than the levels reported for F. capensis bark and F. capensis leaves respectively (Uzoekwe et al., 2013), but

lower than the amount found in C. odorata (Asekun et al., 2013).

The low crude fat value of the sample means that the fruit may be recommended as part of weight reducing diet for those suffering from obesity. Gordon and Kessel (2002) reported that low fat foods help to reduce cholesterol level and obesity. The total carbohydrate content found in this study was comparable to the value obtained from F. capensis bark but much higher than the value for F. capensis leaves (Uzokwe et al., 2013) but the total carbohydrate content indicated by Oko et al., (2012) for U. trimervis was much lower.

The calorific value of the fruits of F. capensis was found to be higher than the value for A. wilkensiana but lower than the value for T. procumbens (Ikewuchi et al., 2012) Aberoumand (2010) also reported higher calorific values for A. officanalis and A. Indica respectively. The low energy value of the fruit highlighted in this study could be attributed to the low protein and lipid content. The results obtained show that the fruits of F. capensis are good sources of minerals (ash), carbohydrate and fiber. Mineral analysis conducted in this study revealed that magnesium had the highest concentration in the fruit of F. capensis but the value is lower than that reported by Uzoekwe at al., (2015) for the leaves and bark of F.capensis, although higher than the magnesium content of the leaves of C.cuyete reported by Olaniyi et al., (2018); but comparable to the level highlighted by Oko et al., (2013) for M. poggei. Magnesium acts an activator of coenzymes involved in the metabolism of carbohydrates and proteins (Vormann, 2003).

On dry weight basis, the potassium value in the fruit sample of $\mathrm{F}$. capensis indicated in this study was lower than that reported for F. capensis bark (Uzoekwe et al., 2013). The concentration of sodium reported in this study on dry weight basis was lower than the value reported by Uzoekwe et al., (2015) for F. capensis, F. capensis bark while Olaniyi et al., (2018) highlighted lower sodium level in their work. Sodium and potassium are extracellular and intracellular ions in humans and they help to maintain electrolyte balance and membrane fluidity (shomar, 2012). Potassium helps to maintain acid-base balance of the hydrogen ion concentration of the body tissues and aids with calcium, magnesium, phosphorous 
and iron to complete protein fats, carbohydrates and vitamins absorption (Islam et al., 2004). The potassium to sodium ratio in the fruit of F. capensis revealed in this study is good for cardiovascular health. The calcium value reported in this study for fruit of F. capensis on dry weight basis was lower than the value for F. capensis leaves and F. capensis bark reported by Uzoekwe et al., (2013) but Olaniyi et al.,

(2018) reported a lower value for C. cujete leaves. Living tissues need calcium as important structural and functional cation. Deficiency of calcium results to bone malformation as well as egg shell formation malformation. Hassan et al., (2004) had reported that calcium is essential and safer for cancer patients than some chemotherapeutic agents that may cause osteopenia and osteoporosis.The iron value on dry weight basis reported in this study was higher than the value reported by Uzoekwe et al., (2015), Okoroh ( 2013) for L. africana, H. crinata, V. amygdalina and T. occidentalis respectively. The fruits of F. capensis was found to be rich in iron in this study. Iron helps in blood haemoglobin formation, meaning that the consumption of the fruit in large amount will help to build the blood of patients suffering from anemia. Mineral analysis revealed that the value of copper was comparable while the value of manganese was lower in the fruits against the values reported by Uzoekwe et al., (2015) in their study for the leaves and bark of F. capensis. Manganese acts as a co-factor in a lot of enzymatic reactions like mucopolysaccharide and glycoprotein synthesis as well as cholesterol and fatty acid biosynthesis (Ghani et al., 2012). Copper plays key role in numerous metabolic reactions and it is involved in growth and several maturation, as a cofactor. The results of mineral analysis highlighted in this study indicated that the fruits of $\mathrm{F}$. capensis are rich in potassium, magnesium and iron but have low levels of calcium, copper and manganese.

Quantitative and qualitative phytochemistry conducted in this study revealed the presence of alkaloid, flavonoid, saponin, tannin, terpenoid, steroid, phenol, cardiac glycoside and resin in the fruits of F. capensis and suggest the use of the plant part for medicinal purpose. This is in agreement with the medicinal characteristics of secondary plant metabolites reported by Temitope and Omotayo (2012); Gill(1992) and Benson and Adeyemi (2007). The result of phytochemical screening of F. capensis leaves and bark (Uzoekwe et al., 2013) also revealed the presence of flavonoids, tannins, cardiac glycosides, alkaloids and terpenoids; while Olaniyi et al., (2018) reported the presence of cardiac glycosides, flavonoids, phenolic compounds, tannins and saponins, and absence of alkaloids and anthroquinones in the leaves of C.cujete. Saponins lower cholesterol level and act as an immune booster as well as an anti-carcinogenic agent (Sodipo et al., 2000), while Okwu and Emenike (2006) reported that saponin play a major role in the treatment of inflammed tissues and cancer prevention. Tannins possess anti-fungal, antibacterial, anti-tumor and anti-viral properties (Sofowora, 2006). The presence of tannins in the fruits of $\mathrm{F}$. capensis strongly supports its use in the treatment of vaginal discharge, tumors and malaria (Taylor, 2005; Farquar, 1996). The presence of flavonoid in the fruits suggests that it may have biological functions such as anti-oxidative and anti-tumor properties (Okwu, 2004). This also supports the anti-inflammatory property of this plant (Lipkin and Newmark, 1999). They can therefore be used in the treatment of hemorrhoids, pains and liver inflammation.

\subsection{Conclusion}

This study highlights that carbohydrate, ash, crude fiber, crude protein and crude fat were present in reasonable amount in the fruit of F. capensis. The study showed that the fruits of F. capensis are potentially rich in tannins, alkaloids, saponin, terpeniod etc. It also revealed that essential minerals (calcium, magnesium, potassium, sodium, iron, copper and manganese) were present. These results therefore suggest that the fruits are good sources of these nutrients which when consumed in appreciable amount will aid in meeting the human nutritional needs for normal growth, development and prevention of deficiency disease. The fruits of this underutilized tropical plant in the south-south Nigeria may therefore be incorporated as source of food and feed supplement based on our findings.

\section{References}

i. Bharucha, Z. and Pretty, J. (2010). The roles and values of wild foods in agricultural system. Phil. Trans. R. Soc. B. 365: 2913-2926

ii. Akubugwo, I. E., Obasi, A. N. and Ginika, S. C. (2007). Nutritional potential of the leaves and seeds of black nightshade-Solanum nigrum L. varvirginicum from Afikpo-Nigeria. Pak. J. Nutri., 6: 323-326.

iii. Berg, C. C. (1991). Moraceace: Ficussurforssk. Flora Zambesiaca 9(6). Retrieved 3 rd January, 2013

iv. Hankey, A. (2003). Ficus sur, plants of South Africa, plant zafrica.com. Retrieved 31 st December, 2012.

v. Mousa, O., Vuorela, P., Kiviranta, I. Abdel, W. S., Hiltunen, R., and Vuorela, H. (2008).

vi. Bioactivity of certain Egyptian Ficus species. Journal of Ethno pharmacology 41(12): 71-76.

vii. AOAC (2006). International official methods of analysis of the AOAC (W. Horwitiz Edition, 18 the dn. Washington D. C., U. S. A: AOAC International.

viii. Harbone, J. B. (1973). Phytochemical methods 3 rd ed. Chapman and Hall Ltd. 135-203. Uzoekwe, S., Mohammed, and Onyibe, H. I. (2013). Nutritional evaluation of Sterculia setigera seeds and pod. PakJ. Biol. Sci. 11:139-141.

ix. Dike, M. C. (2003), Proximate, phytochemical and nutrient composition of some fruits, seeds and leaves of some plant species at Umudike, Nigeria. ARPNJ. Agric Biol. Sci 5:7-16 Olutiola, P. O., Famurewa, O. and Sonntag, H. G., (1991). An introduction to microbiology.

x. Approach to a general practical Heidelberger verlgsansatalt and Druckerei GmbH, Heidelberg, Federal Republic of Germany, pp 267.

xi. Uriah, N. and Izuagbe, Y. (1990) Public health food and industrial Microbiology. Nigeria;

xii. Uniben press, ISBN: 978-2027-00-6

xiii. Andzouana, M. and Mombouli, J. B. (2011). Chemical composition and phytochemical screening of the leaves of Hymenocardiaaul moides and Viterefenuginea. Pak. J. Nutri., 10: 1183-1189 
xiv. Ayoola, P. B. and Adeyeye, A. (2010). Effect of heating on the chemical composition and physico-chemical properties of Arachis hypogeae (Groundnut) seed flour and oil, Pakistan Journal of Nutrition, 9(8): 751-754.

xv. Ishida, A., Toma, T., Ghozali, D. I. , Marjenah (2000). In situ study of the effects of elevated temperature on photoinhibition in climas and pioneer species. In rain forest ecosystems of east Kalimantan: El Nino, Drought, Fire and Human impacts. Ecological studies, vol.

xvi. 140 Eds. E. Guhardja, M. Fatawi, M. Sutisna, T. Mori and S. Olita. Springer - Verlag, Tokyo, pp 269-280.

xvii. Benson, A. and Adeyemi, S. O. (2007). Evaluation of antibacterial properties of tannins isolated from Dichrostachy scinerea. African Journal of Biotechnology 6(15); 1785-1787

xviii. Danlami,U. ,David,B.M. , Thomas, S. A. (2012). "The phytochemical, proximate and elemental analysis of S. gavirosa leaf extracts". Research Journal in engineering and applied science 1(6), 351-354.

xix. Oko, A. O., Okigbo, J. C. Idenyi, J. N. and Ehihia, L. U. (2012). "Nutritional and phytochemical compositions of the leaves of M. poggei". Journal of Biology and Life Science 3(1), 232- 240.

xx. Aberoumand, A. (2010). A comparative study of composition analysis of plants consumed in India and Iran. American-Euroasian Journal of Agriculture and Environmental Science. 8(3): 329-333.

xxi. Ikewuehi, J. C. Onyeike, E. N. , Uwakwe, A. A. (2012). Nutritional potential of the leaves of A. wilkensia Godseffiana Muell Arg. Journal of Applied Science and Environmental Management 14(3), 21-24

xxii. Vorman, J. (2003). “Magnesium: Nutrition, 4 th edn. London”. McGraw Hill.

xxiii. Shomar, S. (2012). "Major and trace elements in Nigella sativa provide a potential mechanism for its healing effects". Journal of Medicinal plants research 6(34) 4836-4843

xxiv. Hassan, L. G., Abdulrahaman, F. N. , Zuru, A. A. (2004). "Nutritional and phytochemical investigation of Diospyros mespiliformi (L.)" Nigerian Journal of Basic Applied Science 13:1-8

xxv. Ghani, A., Ali, Z, Ishiaq, M., Maqbool, M. Parveen, S. (2012). "Estimation of macro and micro nutrients in some important medicinal plants of Soon valley district khushab, Pakistan'.

xxvi. African Journal of Biotechnology 11(78), 14386-14391.

xxvii. Gill, L. S. (1996). Ethno-botanical uses of plants in Nigeria. University of Benin press, Benin city, 350p.

xxviii. Gordon, M. N. and Kessel, M. (2002). Perspective in nutrition, McGraw Hill company.

xxix. Temitope, I. B. , Omatayo, F. O. (2012). Comparative phytochemical analysis of selected medicinal plants in Nigeria. International Journal of Advanced Chemical Research 1(1), 11-18.

xxx. Olaniyi, M.B., Lawal, B.O., Olaniyi, A.A.(2018).Proximate, phytochemical screening , and mineral analysis of Crescentia cujete L. leaves. Journal of Medicinal Plants for Economic Development,2(1),a28.https:/ / doi.org/ 10.4102/ jumped.v2i1.28

xxxi. Islam, Md Rezuanul., Paul, D.K. and Shaha, R.K. (2004).Nutritional importance of some leafy vegetables in Bangladish. Parkistan Journal of Biological Science, 7(8): 1380-1348.

xxxii. Okwu, D.E., Emenike, I.N.(2006). Evaluation of the phytonutrients and vitamin contents of citrus fruits. International Journal of Molecular Medicine and Advance Science 2(1), 1-

xxxiii. Sodipo, A.O., Akiniyi, J.A. and Ogunbamosu, J.A. (2000). Studies on certain characteristics os extracts of bark of Pausinystalla macroceras (K schemp) PierreExbeille, Global Journal of Pure and Applied Sciences 6, 83-87. https:/ / dol.org/ 10.4314/ gjpas. v6/ 1.16082

xxxiv. Tailor, L(2005) Bitter melon, 'Herbal properties and actions', In Tailor (ed.), The healing power of rainforest herbs, pp. 1-5, Rain tree Nutrition Incorporation., New York.

xxxv. Sofowora, A.(2006) Medicinal plants and traditional medicine in Africa, 2 nd edn., Spectrum

xxxvi. Books Ltd., Ibadan, Nigeria,pp.151-153, 209-214.

xxxvii. Okwu, D.E. (2004). Phytochemicals and vitamin content of indigenous spices ofSouth Eastern Nigeria. Journal of Sustainable Agriculture and Environment 6, 30-34.

xxxviii. Farquar, J.N. (1996). Plant sterols, their biological effects in humans, handbook of lipids in nutrition, CRCPress, Boca Rotan, FL,pp.101-105.

xxxix. Lipkin, M., Newmark, H.L. (1999). Vitamin D, calcium and prevention of breast cancer: A cancer review. Journal the American college of Nutrition 18(5), 392-397.

xl. Okoroh, P.N.(2013).Nutrient and antinutrient composition of selected wild and domesticated green leafy vegetables consumed in South East, Nigeria.M.SC thesis, Department of

xli. Biochemistry,Faculty of Science, University of PortHarcourt, Nigeria. Obadoni, B.O., Ochuko, P.O. (2001).Phytochemical studies of comparative efficacy of extracts of some botanical plants in Edo and Delta States of Nigeria. Global Journal of Pure and Applied Sciences. B: 203-208 